\title{
Ovarian follicular development and endocrine responses in follicular-fluid-treated and hemi-ovariectomized heifers
}

\author{
J. G. Lussier ${ }^{1}$, P. Matton ${ }^{2}$, L. A. Guilbault ${ }^{3 *}$, F. Grasso ${ }^{3}$, \\ R. J. Mapletoft ${ }^{4}$ and T. D. Carruthers ${ }^{4}$ \\ ${ }^{1}$ CRRA, Faculté de médecine vétérinaire, Université de Montréal, St-Hyacinthe, Quebec, Canada J2S 7C6; \\ ${ }^{2}$ Faculté des sciences, Université de Sherbrooke, Sherbrooke; ${ }^{3}$ Agriculture Canada Research Station, \\ Lennoxville; and ${ }^{4}$ Western College of Veterinary Medicine, University of Saskatchewan, Saskatoon, \\ Canada
}

The effects of charcoal-extracted bovine follicular fluid (BFF) on endocrine profiles and follicular development in intact and hemiovariectomized postpubertal heifers were examined. Oestrus-synchronized heifers received Norgestomet implants on day 1 and 7 of treatment and were then injected s.c. with $11 \mathrm{ml}$ saline (control) or $11 \mathrm{ml} \mathrm{BFF}$ twice a day for 12 days. The ovary bearing the largest follicle $\left(O V_{1}\right)$ was removed on day 7 and the remaining ovary $\left(\mathrm{OV}_{2}\right)$ was collected on day 13 . Follicles were observed by daily ultrasonography and were classified according to diameter (size $1: 2-3 \mathrm{~mm}$; size 2: 4-6 mm; size 3: 7-10 mm; size 4: >10 mm). After ovariectomy they were classified by diameter and histologically as normal or atretic. Intact control heifers had increased numbers of size 4 follicles on $\mathrm{OV}_{1}$ on days 6 and 7; no increase was observed in BFF-treated heifers $(P<0.03)$. In BFF-treated heifers, the mean basal LH concentration was higher $(P<0.05)$ and that of FSH was lower $(P<0.04)$ than in controls. FSH concentrations in BFF-treated heifers decreased from $0.60 \pm 0.08 \mathrm{ng} \mathrm{ml}^{-1}$ (day 1) to $0.22 \pm 0.05 \mathrm{ng} \mathrm{ml}^{-1}$ (day $7 ; P<0.04$ ). The concentration of oestradiol increased in control heifers, but not in BFF-treated heifers $(P<0.001)$. After hemicastration, $\mathrm{OV}_{2}$ underwent compensatory hypertrophy in control heifers, with an increase in the number of size 2,3 and 4 follicles $(P<0.05)$, whereas BFF-treated heifers did not. Thus, total follicular volume was much lower in BFF-treated than in control heifers on day $13\left(92.2 \pm 15.4\right.$ versus $\left.1393.8 \pm 276.6 \mathrm{~mm}^{3} ; P<0.0002\right)$. A transient increase in FSH $(P<0.006)$ and oestradiol $(P<0.01)$ concentrations occurred after hemiovariectomy in control but not in BFF-treated animals. In control heifers, an analysis of temporal relationships showed negative correlations between the volume of size 3 and size 4 follicles, and between FSH concentrations and the volume of size 3 and 4 follicles. A positive correlation was found between the mean diameter of the largest follicle and the concentration of oestradiol, whereas negative relationships were found between the concentrations of FSH and oestradiol, and between FSH and the mean diameter of the largest follicle. Analysis of the histological data showed that the number and volume of follicles $>8.57 \mathrm{~mm}$ was lower in the BFF-treated $\mathrm{OV}_{1}$ ovary, whereas no differences were found for follicles $\leq 8.57 \mathrm{~mm}$. An absence of or a lower number and volume of follicles $\geq 3.68 \mathrm{~mm}$ was observed in BFF-treated $\mathrm{OV}_{2}$ compared with controls. We showed that: (i) compensatory hypertrophy in the remaining ovary occurs in heifers when the ovary bearing the largest follicle is removed; (ii) treatment with BFF decreases the FSH concentration and follicular development in intact postpubertal heifers, and prevents compensatory FSH increase and follicular growth after unilateral ovariectomy; and (iii) the histological population of follicles $<3.68 \mathrm{~mm}$ in diameter are not altered following 12 days of BFF treatment. Our results suggest that follicular development beyond 3-4 $\mathrm{mm}$ in cattle depends on an adequate circulating concentration of FSH.

\section{Introduction}

Development of antral follicles during the oestrous cycle in cattle is characterized by two or three successive periods of 
follicular development. Each consists of a phase during which follicles are recruited, followed by a phase of follicular selection that results in one selected follicle continuing its development into a dominance phase. The dominance phase is characterized by the growth of one large follicle $(>10 \mathrm{~mm})$ per pair of ovaries (Webb et al., 1992; Fortune, 1994). However, more information on the physiological mechanisms leading to follicular recruitment, selection and dominance is required to understand the control of follicular kinetics in cattle.

Injection of charcoal-extracted bovine follicular fluid (BFF) selectively reduces circulating FSH concentrations in intact (Miller et al., 1979; Lussier and Carruthers, 1989; Moser et al., 1989; Zollers et al., 1989; Turzillo and Fortune, 1990, 1993; Adams et al., 1992; Wood et al., 1993), hemiovariectomized (Johnson et al., 1985; Moser et al., 1989) and ovariectomized cattle (Ireland et al., 1983; Beard et al., 1989, 1990), and the spontaneous release of FSH by bovine pituitary cells in culture (Lussier et al., 1993). The decrease in FSH concentration caused by the injection of follicular fluid was attributed to the action of inhibin on the anterior pituitary (Knight, 1991; Dalkin et al., 1993). Miller ef al. (1979) and Quirk and Fortune (1986) observed delayed oestrus following luteolysis induced by $\mathrm{PGF}_{2 a}$ when BFF was injected; the delay was related to the volume and duration of the BFF injections. We observed that the superovulatory response is altered following pretreatment with BFF for 6 days in cyclic heifers (Lussier and Carruthers, 1989). These studies suggest that BFF alters follicular development, although follicular development was not monitored during or following the BFF treatments.

Injection of BFF suppresses the postovulatory increase in the FSH concentration, delays normal follicular development following oestrus (Turzillo and Fortune, 1990) and prevents the growth of a dominant follicle (Kastelic et at., 1990; Adams et al., 1992; Turzillo and Fortune, 1993). Ovarian compensatory hypertrophy following unilateral ovariectomy has been reported in cyclic and postpartum cows (Hafez ef al., 1964; Saiduddin et al., 1970; England et al., 1973; Merz et al., 1977; Grass and Hauser, 1981; Staigmiller and England, 1982) and in prepubertal heifers (Johnson et al., 1985; Moser et al., 1989). In some of these studies, hormonal responses were only partially evaluated and follicular development was not monitored during the compensatory response. There is no information about the effects of BFF on follicles $<4-5 \mathrm{~mm}$, probably owing to the limited resolution of ultrasonography. The present experiment was therefore designed to investigate the effects of charcoal-extracted BFF on circulating hormone concentrations and on follicular development, as monitored by ultrasonography, macroscopic observations of ovarian structures, and histology of antral follicle populations in intact and hemiovariectomized postpubertal beef heifers.

\section{Materials and Methods}

\section{Animals and treatments}

Twelve crossbred beef heifers with a mean ( \pm SEM) bodymass of $384.6 \pm 6.7 \mathrm{~kg}$ were randomly assigned to two treatment groups and held in the same pen. The heifers were synchronized for oestrus with two injections of cloprostenol
(500 $\mu$ g, i.m.; Estrumate: Cooper's Agropharm, Ajax, Ontario) 11 days apart. On the morning of the second cloprostenol injection (day I), heifers received a Norgestomet ear implant (Syncro-Mate-B: CEVA, Kansas City, KS) to prevent ovulation. The heifers were either injected with $11 \mathrm{ml}$ saline s.c. (the control group) or $11 \mathrm{ml}$ charcoal-extracted BFF s.c. (the BFFtreated group) at $12 \mathrm{~h}$ intervals. (The $11 \mathrm{ml}$ dose of BFF was chosen since it had previously been found that injections of 7 or $14 \mathrm{ml}$ given s.c. for 6 days decreases circulating FSH concentrations; Lussier and Carruthers, 1989). The treatments began on day 1 and continued for 12 days.

On the morning of day 7, the first Norgestomet implant was replaced with a new implant and the ovary bearing the largest follicle $\left(O V_{1}\right)$, as determined by daily ultrasonography (from day 1), was removed. The use of a Norgestomet implant prevented the possibility of removing ovaries bearing or not bearing corpora lutea on day 7 or 13 . On the morning of day 13 , the remaining ovary $\left(\mathrm{OV}_{2}\right)$ was collected. The treatment with BFF for 6 days before removing each ovary was intended to allow time for effects on the small and medium-sized antral follicles to be manifested, since development and maturation of these follicles requires approximately 6.9 days, as estimated by Lussier et al. (1987). Follicular fluid used for treatments was collected and processed as described by Lussier and Carruthers (1989). The charcoal treatment removed $>97.5 \%$ of the steroids in BFF; the final concentrations were: $2.7 \mathrm{ng}$ progesterone $\mathrm{ml}^{-1}, 0.5 \mathrm{ng}$ oestradiol $\mathrm{ml}^{-1}$ and $1.7 \mathrm{ng}$ testosterone $\mathrm{ml}^{-1}$.

Ovariectomies were performed by right flank laparotomy under local anaesthesia in standing heifers. Heifers were tranquillized with an injection of $10 \mathrm{mg}$ acepromazine maleate i.m. (Atravet: Ayerst Laboratories, Montreal) $30 \mathrm{~min}$ before surgery, and the surgical site disinfected. Lidocaine $\mathrm{HCl}$ (with $2 \%$ adrenaline; MTC Pharmaceutic Ltd, Cambridge, Canada) was infused to desensitize the surgical site (Short, 1987), and the ovaries were obtained using an ovariotome. The animals were injected with $15000 \mathrm{iu}$ penicillin $\mathrm{kg}^{-1} \mathrm{i}$ i.m. (MTC Pharmaceutic Ltd) beginning $12 \mathrm{~h}$ before the surgery and at $12 \mathrm{~h}$ intervals for 3 days.

\section{Endocrine analysis}

Endocrine profiles were assessed by taking heparinized and nonheparinized jugular blood samples at intervals of $12 \mathrm{~h}$ (08:00 h and 20:00 h) before BFF treatment. The nonheparinized samples were allowed to clot at room temperature $\left(22^{\circ} \mathrm{C}\right)$ for $4-6 \mathrm{~h}$. The heparinized samples were cooled immediately to $4^{\circ} \mathrm{C}$ and centrifuged $\left(2000 \mathrm{~g}, 15 \mathrm{~min}, 4^{\circ} \mathrm{C}\right.$ ) within $2 \mathrm{~h}$. Serum and plasma were then frozen at $-20^{\circ} \mathrm{C}$ until assayed. Endogenous gonadotrophin concentrations were determined by double antibody radioimmunoassays in serum as described by Lussier and Carruthers (1989), except that the tracers were iodinated by lodogen (Pierce Chemicals, Rockford, IL). Briefly, FSH or LH (2.5-5 $\mu \mathrm{g})$ was diluted with $20-35 \mu \mathrm{l}$ of $0.5 \mathrm{~mol}$ phosphate buffer $\mathrm{l}^{-1}(\mathrm{pH} 7.4)$, transferred to a capped vial containing $I \mu \mathrm{g}$ lodogen, and allowed to react for 6-7 min with $500 \mu \mathrm{Ci}^{125} \mathrm{I}$ (Amersham, Oakville). Labelled hormones were separated from free ${ }^{125}$ I salt by chromatography on to a G-25 Sephadex column (PD-10; Pharmacia, Montreal). The 
specific activity of the tracers was estimated at $45-55 \mu \mathrm{Ci}$ $\mu \mathrm{g}^{-1}$.

Serum FSH concentrations were determined in a single assay as described by Lussier and Carruthers (1989). Briefly, we used ovine FSH (NIAMDD-oFSH-I-I) as the tracer, ovine FSH (NIAMDD-oFSH-RP-1) as the standard, rabbit anti-ovine FSH (NIAMDD-anti-oFSH-I) as the first antibody, and sheep antirabbit $\gamma$-globulin (J. G. Manns, University of Saskatchewan, Saskatoon) as the precipitating second antibody. The sensitivity of the assay was $0.06 \mathrm{ng}$ per tube $\left(0.30 \mathrm{ng} \mathrm{ml}^{-1}\right)$ and the intra-assay coefficient of variation was $5.1 \%$.

Serum LH concentrations were determined in a single assay as described by Lussier and Carruthers (1989). Briefly, the assay used bovine LH (LER-1716-2; L. E. Reichert, Union University, Albany, NY) as the tracer, NIH-bLH-B10 as the standard, and rabbit anti-ovine $\mathrm{LH}$ as the first antibody (GDN no. 15; Dr G. D. Niswender, Colorado State University, Fort Collins, $\mathrm{CO}$ ). The sensitivity of the assay was $0.025 \mathrm{ng}$ per tube $\left(0.125 \mathrm{ng} \mathrm{ml}^{-1}\right)$ and the intra-assay coefficient of variation was $10.8 \%$.

For steroid analysis, follicular fluid and plasma $(200 \mu \mathrm{l})$ were extracted with $3 \mathrm{ml}$ hexane (BDH Chemicals, Montreal, Quebec), with $80.9 \%$ recovery, and the concentration of progesterone was determined in a single $\left[{ }^{125} \mathrm{I}\right]$ progesteronebased assay as described by Rawlings et al. (1984). The sensitivity of this double antibody assay was $25 \mathrm{pg}$ per tube $\left(0.125 \mathrm{ng} \mathrm{ml}^{-1}\right)$ and the intra-assay coefficient of variation was $7.8 \%$. Serum oestradiol $(500 \mu \mathrm{l})$ and follicular fluid were determined in a single tritium-based assay as described by Rowell and Flood (1988) after extraction with $4 \mathrm{ml}$ ethyl ether (Caledon Labs, Georgetown, Ontario), with $85 \%$ recovery. The sensitivity of the assay was I pg per tube $\left(2 \mathrm{pg} \mathrm{ml}^{-1}\right)$ and the intra-assay coefficient of variation was $16.9 \%$. Testosterone from follicular fluid was extracted using diethyl ether and the concentration was determined with a tritium-based assay as described by Cook et al. (1982), with a sensitivity of 5 pg per tube.

\section{Ovarian analysis}

Each morning of the experiment (day 1-day 13), except on day 12 because of technical difficulties, ovaries were scanned by linear-array ultrasonography (LS-300A; Tokyo Keiki Co. Ltd, Tokyo) using a $7.5 \mathrm{MHz}$ transducer probe. The ovaries were localized by rectal palpation and scanned in a medial to lateral direction so that the follicles present could be observed (Guilbault et al., 1991). Each follicle was measured directly on the video screen using a calliper. The mean diameter was calculated with two perpendicular measurements and the approximate volume was calculated. Follicles were classified according to their diameter: size $1,2-3 \mathrm{~mm}$; size 2, 4-6 mm; size $3,7-10 \mathrm{~mm}$ and size $4,>10 \mathrm{~mm}$.

After ovariectomy, the diameter of each visible follicle was measured macroscopically with a calliper applied directly on the ovarian surface; the volume was calculated and the size categorized according to diameter as described for ovarian ultrasonography data. The ovaries were embedded in paraffin wax, serially sectioned at a thickness of $7 \mu \mathrm{m}$, and every tenth section was mounted and stained in haematoxylin. All antral follicles $>0.13 \mathrm{~mm}$ were classified according to their largest diameter: class 2, 0.13-0.28 mm; class 3, 0.29-0.67 mm; class 4, $0.68-1.52 \mathrm{~mm}$; class $5,1.53-3.67 \mathrm{~mm}$; class $6,3.68-8.57 \mathrm{~mm}$; class 7, > $8.57 \mathrm{~mm}$ (Lussier et al., 1987).

Each follicle was classified as normal or atretic according to criteria similar to those used by Grimes et al. (1987). Nonatretic follicles had well attached granulosa cells, with a regular internal border and an antrum with no cellular debris. The basal membrane was present, basal granulosa cells were cylindrical and pyknotic cells were either absent or scarce $(<1 \%)$. In follicles with first degree atresia, granulosa cells were loosely attached and the internal border was irregular, pyknotic cells were present $(1-8 \%$ ), and cellular debris was often present in the antrum; the basement membrane and cylindrical basal granulosa cell layer were poorly defined and the theca interna was often thickened. In second degree atresia, $50 \%$ or more of the granulosa cells were lost, pyknotic cells were abundant and the theca interna was 2-3 times thicker than normal. Third degree atresia was characterized by an almost complete absence of granulosa cells (only 1-2 layers of cells with reduced area; i.e. nucleus and cytoplasm) and the presence of several pyknotic cells.

\section{Statistical analyses}

Ovarian follicular ultrasonography data and endocrine data were compared by analysis of variance (ANOVA) on raw data using a split-plot design with repeated measures in time. The general linear model (GLM) procedure of SAS (SAS, 1985) was performed with treatments as the main effect from day 1 to day 7 (before hemiovariectomy) and from day 7 to day 13 (following removal of $\mathrm{OV}_{1}$ ). Comparisons between treatment groups for each day were done by orthogonal polynomial contrasts, with degrees of freedom adjusted by the Greenhouse-Geisser Epsilon correction factor (Allen et al., 1983; SAS, 1985). The temporal relationship between FSH and oestradiol concentrations and follicular numbers or volumes per size within control heifers from day 1 to day 13 , were performed by partial correlation analysis.

Macroscopic observations were compared by one-way ANOVA for numbers of follicles or volumes per follicular size, with treatment or ovariectomy as main effects, comparing $O V_{I}$ or $\mathrm{OV}_{2}$, and within control or BFF-treated heifers comparing $\mathrm{OV}_{1}$ and $\mathrm{OV}_{2}$. Histological observations were compared by one-way ANOVA with respect to the absolute number or relative number of follicles, and absolute follicular volume for each class, with treatment as main effect, comparing $\mathrm{OV}_{1}$ or $\mathrm{OV}_{2}$, and within treatment group, comparing $\mathrm{OV}_{1}$ and $\mathrm{OV}_{2}$. The relative number of follicles per class represent the number of follicles in each class expressed as a percentage of the total number of antral follicles present in the ovary. The diameter of each follicle (as determined by histological observations) was increased by $20 \%$ to correct for shrinkage during fixation and embedding (Kruip and Dieleman, 1982; J.G. Lussier and P. Matton, unpublished) to allow comparisons of macroscopic and ultrasonography data. Follicles were reclassified according to macroscopic observations to allow numbers of follicles to be determined histologically, macroscopically and ultrasonographically on day 7 and day 13 to be analysed by 

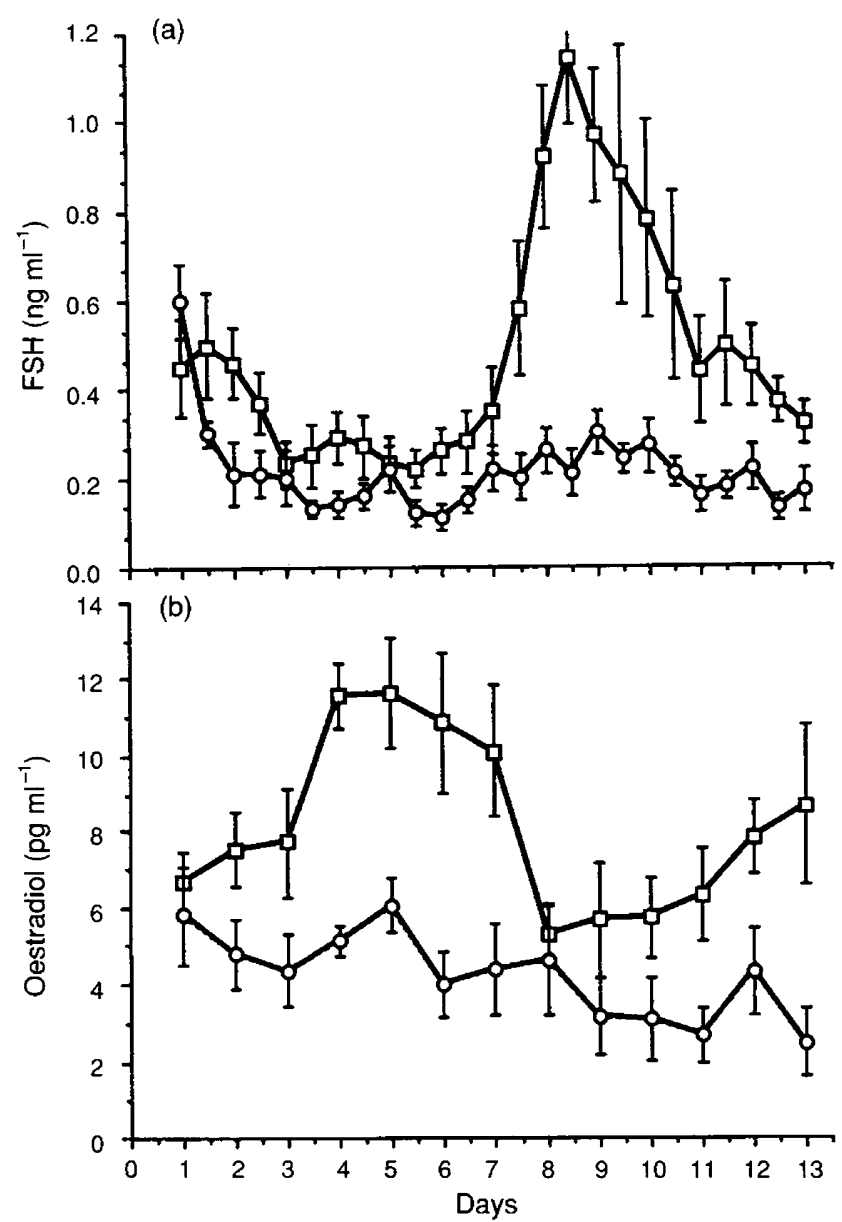

Fig. 1. Mean ( \pm SEM) concentrations of (a) FSH (ng ml ${ }^{-1}$ ) and (b) oestradiol $\left(\mathrm{pg} \mathrm{ml}^{-1}\right)$ in heifers from which the ovary bearing the largest follicle $\left(\mathrm{OV}_{1}\right)$ was removed on day 7 and the remaining ovary $\left(\mathrm{OV}_{2}\right)$ removed on day 13 . Heifers were treated from day 1 to day 13 with saline (control; $n=5 ; \square$ ) or charcoal-extracted bovine follicular fluid (BFF; $n=6 ; 0)$.

Pearson's correlation analysis. Precision in the number of follicles estimated by these three methods was calculated by the following equation: $P=\left\{1-\left[\Sigma\left(Y_{i}-X_{i}\right) / \Sigma Y_{i}\right]\right\} \times 100$; where $Y_{i}=$ the number of follicles determined histologically and $X_{i}=$ the number of follicles estimated macroscopically or ultrasonographically (Monniaux et al., 1983). One control heifer had to be removed from the analysis because adhesions on the ovaries prevented ultrasonography and ovariectomy and also because hormonal profiles differed from others in the same treatment group.

\section{Results}

Endocrine and ovarian ultrasonography analysis

Intact heifers. Injection of BFF reduced the endogenous circulating FSH concentrations in the BFF-treated heifers from $0.60 \pm 0.08 \mathrm{ng} \mathrm{ml}^{-1}$ on day 1 to $0.22 \pm 0.05 \mathrm{ng} \mathrm{ml}^{-1}$ on day 7 (Fig. 1). The mean concentration of FSH for the entire period (days $1-7)$ was lower $(P<0.04)$ in the BFF-treated group, with

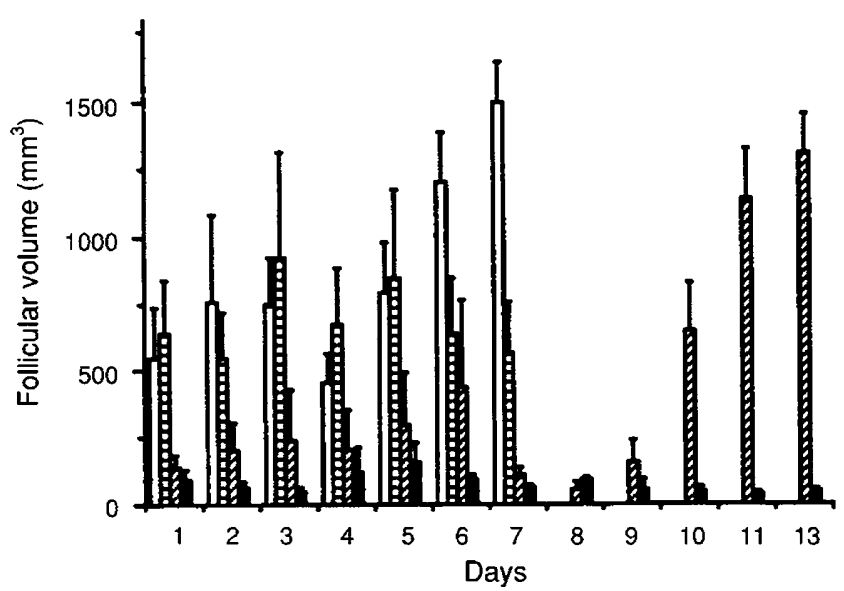

Fig. 2. Mean total volume ( \pm SEM) of follicles per ovary as observed by daily ultrasonography scanning in heifers from which the ovary bearing the largest follicle $\left(\mathrm{OV}_{1}\right)$ was removed on day 7 and the remaining ovary $\left(\mathrm{OV}_{2}\right)$ removed on day 13 . Heifers were treated from day 1 to day 13 with saline $\left(n=5\right.$; control $O V_{1}, \square$; control $O V_{2}, \square$ ) or charcoal-extracted bovine follicular fluid $\left(n=6 ; \mathrm{BFF} \mathrm{OV}_{1}\right.$, 目; BFF $\mathrm{OV}_{2}, \mathbf{\square}$ )

an effect of time $(P<0.0001)$ and a tendency towards a time by treatment interaction $(P<0.07)$. The mean basal LH concentration from day 1 to day 7 was higher $(P<0.05)$ in the BFF-treated heifers $\left(0.81 \pm 0.28 \mathrm{ng} \mathrm{ml}^{-1}\right)$ compared with controls $\left(0.34 \pm 0.12 \mathrm{ng} \mathrm{ml}^{-1}\right)$, but no time or treatment by time interactions were detected. The initial concentration of progesterone ( $1.2 \pm 1.6 \mathrm{ng} \mathrm{ml}^{-1}$ ) decreased in both groups and reached basal concentrations $\left(<0.15 \mathrm{ng} \mathrm{ml}^{-1}\right.$; effect of time, $P<0.0008$ ) within $24 \mathrm{~h}$ after cloprostenol injection. From day $\mathrm{I}$ to day 7 , the concentration of progesterone remained low and no treatment or treatment by time interactions were observed. Control heifers displayed increasing concentrations of oestradiol from day 1 to day 7 (Fig. 1), but remained constant in BFF-treated heifers $(P<0.07$; time and time by treatment interaction); likewise, the overall mean concentration of oestradiol was higher in control than in BFF-treated heifers $(P<0.002)$.

The analysis of ovarian ultrasonography data from day 1 to day 7 indicated no significant differences between control and BFF-treated heifers with respect to follicular volume or the number of follicles $<10 \mathrm{~mm}$ in the ovary bearing the largest follicle $\left(\mathrm{OV}_{1}\right.$; Figs 2 and 3$)$. However, there was an increase in the follicular volume $(P<0.03)$ and the number $(P<0.03)$ of size 4 follicles $(>10 \mathrm{~mm})$ in control but not in BFF-treated heifers on days 6 and 7 (Fig. 3). The analysis of total number of follicles between day 1 and day 7 showed an effect of time $(P<0.02)$, whereas time $(P<0.05)$ and treatment by time effects $(P<0.02)$ were observed for the total follicular volume (Fig. 2) in $\mathrm{OV}_{1}$. No differences were observed between the BFF-treated and control heifers in the number or volume of follicles in $\mathrm{OV}_{2}$ between day $\mathrm{I}$ and day 7. The mean diameter of the largest follicle on control $\mathrm{OV}_{1}$ was $8.0 \mathrm{~mm}$ on day 4 and $13.0 \mathrm{~mm}$ on day 7 , and the mean follicular growth rate was estimated at $1.66 \mathrm{~mm}$ day $^{-1}$.

Hemiovariectomized heifers. Concentrations of FSH after hemiovariectomy (days 8-13) remained low in the BFF-treated 

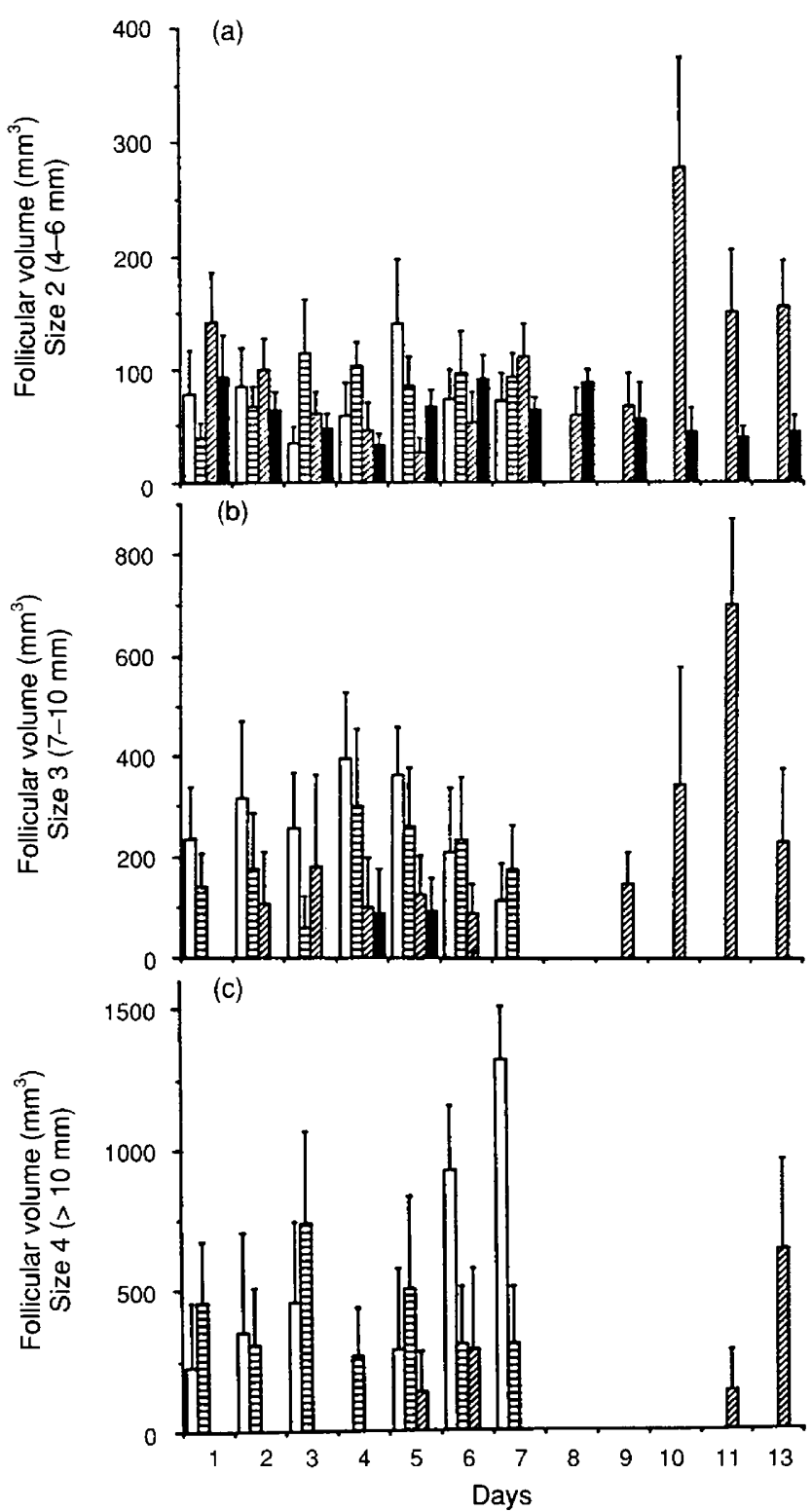

Fig. 3. Mean volume $( \pm$ SEM) of follicles per ovary of diameter (a) 4-6 mm (size 2), (b) 7-10 mm (size 3) and (c) $>10 \mathrm{~mm}$ (size 4), as observed by daily ultrasonography scanning in heifers from which the ovary bearing the largest follicle $\left(O V_{1}\right)$ was removed on day 7 and the remaining ovary $\left(\mathrm{OV}_{2}\right)$ on day 13 . Heifers were treated from day $\mathrm{I}$ to 13 with saline $\left(n=5\right.$; control $\mathrm{OV}_{1}, \square$; control $\left.\mathrm{OV}_{2}, \mathrm{Q}\right)$ ) or charcoalextracted bovine follicular fluid ( $n=6$; $\mathrm{BFF} \mathrm{OV} \mathrm{1}$, 国; $\left.\mathrm{BFF} \mathrm{OV}_{2}, \boldsymbol{\square}\right)$.

group until the second ovary was removed on day 13 (Fig. 1). However, in control heifers, concentrations of FSH rose from $0.35 \pm 0.1 \mathrm{ng} \mathrm{ml}^{-1}$ to $0.58 \pm 0.15 \mathrm{ng} \mathrm{ml}^{-1}$ within $12 \mathrm{~h}$ of hemiovariectomy, reached a maximum of $1.14 \pm 0.15 \mathrm{ng} \mathrm{ml}^{-1}$ after approximately $36 \mathrm{~h}$, and decreased thereafter to a prehemicastration concentration of $0.32 \pm 0.05 \mathrm{ng} \mathrm{ml}^{-1}$. The overall mean FSH concentration remained higher in control $(P<0.006)$ than in the BFF-treated heifers $(0.17 \pm 0.05 \mathrm{ng}$ $\mathrm{ml}^{-1}$ on day 13). The concentrations of FSH between the control and BFF-treated heifers showed effects of treatment $(P<0.003)$, time $(P<0.003)$ and time by treatment $(P<0.02)$ interactions. Ten days after removing the second ovary, FSH concentrations rose to $2.42 \pm 0.19 \mathrm{ng} \mathrm{ml}^{-1}$ and $2.54 \pm 0.15 \mathrm{ng}$ $\mathrm{ml}^{-1}$ in the control and BFF-treated groups, respectively, and were not different.

Concentrations of LH tended to increase in both groups within $36 \mathrm{~h}$ of hemicastration, from $0.28 \pm 0.12 \mathrm{ng} \mathrm{ml}^{-1}$ to $0.51 \pm 0.13 \mathrm{ng} \mathrm{ml}^{-1}$ in controls and from $1.37 \pm 0.42 \mathrm{ng} \mathrm{ml}^{-1}$ to $1.71 \pm 0.47 \mathrm{ng} \mathrm{ml}^{-1}$ in BFF-treated heifers. The concentration of LH in the BFF-treated heifers following hemiovariectomy had a mean value of $1.57 \pm 0.57 \mathrm{ng} \mathrm{ml}-1$ between day 7 and day 13 compared with $1.03 \pm 0.46 \mathrm{ng}$ $\mathrm{ml}^{-1}$ in control heifers. Concentrations of LH varied with time $(P<0.02)$, but no treatment or treatment by time interaction effects were observed. Ten days after removing $\mathrm{OV}_{2}$, the concentration of $\mathrm{LH}$ in controls and BFF-treated heifers rose to $4.84 \pm 1.69$ and $3.39 \pm 1.16 \mathrm{ng} \mathrm{ml}^{-1}$, respectively.

Concentrations of progesterone remained low in both groups and were below the sensitivity limit of the assay.

Concentrations of oestradiol began to rise slightly on day 12 ( 5 days after hemicastration) in control but not in BFF-treated heifers, so that the mean concentration of oestradiol between day 7 and day 13 was higher $(P<0.01)$ in control than in BFF-treated heifers (Fig. 1). No effect of time $(P<0.09)$ or time by treatment interactions $(P<0.16)$ were noticed. After $\mathrm{OV}_{2}$ was removed plasma concentrations of oestradiol decreased below the sensitivity limit of the radioimmunoassay in both groups.

The analysis of ovarian ultrasonography data obtained from $\mathrm{OV}_{2}$ from day 7 to day 13 showed an effect of time $(P<0.03)$ on the number of size $I$ follicles, but no treatment or treatment by time interaction was observed between the control and BFF-treated heifers with respect to the number or volume of follicles (data not shown). There were more size 2 follicles $(P<0.02)$ in the control than in the BFF-treated heifers on days 10,11 and 13 (Fig. 3). The number of size 3 and 4 follicles increased within 2 and 4 days of hemicastration, respectively, in control heifers (time by treatment interaction; $P<0.05 ; P<0.04$ ), while these types of follicle were completely absent in BFF-treated heifers. When the total number of follicles in BFF-treated and control heifers were compared, an effect of time was observed $(P<0.004)$, as well as a tendency towards a time by treatment interaction $(P<0.07)$. Analysis of the follicular volume of size 2,3 and 4 follicles (Fig. 3) or the total follicular volume (Fig. 2) displayed treatment $(P<0.03 ; P<0.002 ; P<0.01 ; P<0.0001)$, time $(P<0.1 ; P<0.02 ; P<0.08 ; P<0.0003)$ and treatment by time interactions $(P<0.02 ; P<0.02 ; P<0.08 ; P<0.0002)$. An increase in the volume of size 2 follicles was first detected on day 10 ( $72 \mathrm{~h}$ after hemiovariectomy) and was maintained until day 13 , whereas the volume of size 3 follicles began to increase on day 9 ( $48 \mathrm{~h}$ after hemiovariectomy). Follicles $>10 \mathrm{~mm}$ (size 4) were first observed 4 days after hemiovariectomy (Fig. 3). The total follicular volume of $\mathrm{OV}_{2}$ $\left(1393.8 \pm 276.6 \mathrm{~mm}^{3}\right)$ on day 13 approximated the sum of the follicular volumes of $\mathrm{OV}_{1}\left(1553.9 \pm 149.5 \mathrm{~mm}^{3}\right)$ and $\mathrm{OV}_{2}$ $\left(104.7 \pm 10.4 \mathrm{~mm}^{3}\right)$ that were observed before hemicastration (day 7). The mean diameter of the largest follicle on $\mathrm{OV}_{2}$ in the five control heifers was $4.2 \mathrm{~mm}$ on day 8 and $12.2 \mathrm{~mm}$ on day 13 , and the estimated mean follicular growth rate was $1.60 \mathrm{~mm}$ day $^{-1}$. 
Table 1. Least square means ( \pm SEM) of the number of follicles observed macroscopically on day 7 or day 13 in control ovaries compared with ovaries treated with bovine follicular fluid (BFF)

\begin{tabular}{lcccc}
\hline & \multicolumn{2}{c}{$\begin{array}{c}\text { Number of follicles on day } 7 \\
\text { Follicular size }\end{array}$} & Control $\left(\mathrm{OV}_{1}\right)$ & Number of follicles on day 13 \\
& & & $\begin{array}{c}\text { Number }\left(\mathrm{OV}_{1}\right) \\
\text { Control }\left(\mathrm{OV}_{2}\right)\end{array}$ & BFF-treated $\left(\mathrm{OV}_{2}\right)$ \\
\hline Size I $(2-3.9 \mathrm{~mm})$ & $19.0 \pm 8.13$ & $17.67 \pm 7.42$ & $18.8 \pm 9.3$ & $15.5 \pm 8.49$ \\
Size 2 $(4-6.9 \mathrm{~mm})$ & $2.8 \pm 0.81$ & $3.17 \pm 0.74$ & $4.2 \pm 0.85$ & $2.0 \pm 0.78^{\mathrm{c}}$ \\
Size 3 $(7-10 \mathrm{~mm})$ & 0 & $0.33 \pm 0.16$ & $1.6 \pm 0.27$ & $0^{\mathrm{b}}$ \\
Size 4 $(>10 \mathrm{~mm})$ & $1.4 \pm 0.32$ & $0.33 \pm 0.29^{\mathrm{a}}$ & $0.8 \pm 0.13$ & $0^{\mathrm{b}}$ \\
Total per ovary & $23.2 \pm 8.28$ & $21.5 \pm 7.55$ & $25.4 \pm 9.35$ & $17.5 \pm 8.53$ \\
\hline
\end{tabular}

Number of follicles in control and BFF-treated heifers were compared for each follicular size at day 7 or at day 13 ( ${ }^{\mathrm{a}} P<0.05$;

${ }^{\mathrm{b}} \mathrm{P}<0.01 ;{ }^{\mathrm{c}} \mathrm{P}<0.1$.

\section{Temporal relationships between the endocrine profiles and the ovarian ultrasound observations}

The temporal relationships between the endocrine profiles and the ovarian ultrasonography data in control heifers from day $I$ to day 13 were analysed on a within-heifer basis by partial correlation analysis. Negative relationships were found between the concentrations of $\mathrm{FSH}$ and oestradiol $(r=-0.4652, P<0.0002$, d.f. $=59)$, and between FSH and the diameter of the largest follicle $(r=-0.6346, P<0.0001$, d.f. $=54$ ). The concentrations of oestradiol were positively correlated with the diameter of the largest follicle $(r=0.3826$, $P<0.004$, d.f. $=54$ ). A negative relationship was found in control heifers between the number and total volume per heifer of size 3 and size 4 follicles (number: $r=-0.2954, P<0.02$, d.f. $=54$; volume: $r=-0.3600, P<0.006$, d.f. $=54$ ). Furthermore, a positive relationship was found between the number and volume per heifer of size 1 and size 4 follicles (number: $r=0.3218, P<0.02$, d.f. $=54$; volume: $r=0.2758, P<0.04$, d.f. $=54)$. The number and volume of size $I(r=-0.2919$, $P<0.03 ; \quad r=-0.367, \quad P<0.005)$, size $3 \quad(r=-0.3479$, $P<0.009 ; r=-0.3758, P<0.004)$ and size $4(r=-0.3229$, $P<0.01 ; r=-0.2857, P<0.03)$ follicles were negatively correlated with the concentrations of FSH. A positive correlation was observed between the number and volume of size 1 $(r=0.3792, \quad P<0.004 ; \quad r=0.3786, \quad P<0.004)$ and size 4 $(r=0.4189, P<0.001 ; r=0.3853, P<0.003)$ follicles and the concentration of oestradiol.

\section{Analysis of ovarian macroscopic and histological observations}

Macroscopic observations of the ovaries bearing the largest follicle $\left(O V_{1}\right)$ on day 7 following 6 days of treatment showed that there were fewer size 4 follicles in BFF-treated heifers than in control heifers (Table 1 ); in addition, size 4 and total follicular volumes (data not included) were lower in the BFF-treated ovaries. Control ovaries on day $13\left(\mathrm{OV}_{2}\right)$ contained large, hyperaemic follicles, whereas the BFF-treated ovaries appeared yellowish with minimal vascularization and had no follicles $\geq 7 \mathrm{~mm}$ in diameter. BFF-treated heifers had fewer follicles of size $2(P<0.1), 3(P<0.01)$ and $4(P<0.01)$ on $\mathrm{OV}_{2}$. Follicular volume was also lower in follicles of sizes 3 and 4 , as was the total follicular volume per ovary, compared with control ovaries. More size 3 follicles were found on $\mathrm{OV}_{2}$ than on $\mathrm{OV}_{1}$ from control heifers. In the BFF-treated heifers, a smaller total follicular volume was found in $\mathrm{OV}_{2}$ compared with $\mathrm{OV}_{1}$; this was mainly related to fewer follicles $>4 \mathrm{~mm}$ in diameter (data not included).

Analysis of the ovarian histological data showed no statistical differences between the control $\mathrm{OV}_{1}$ or the BFF-treated $\mathrm{OV}_{\mathrm{I}}$ on day 7 for follicles $\leq 8.57 \mathrm{~mm}$ in diameter (Table 2). The absolute or relative number and volume (data not included) of follicles $>8.57 \mathrm{~mm}$ was lower in the BFF-treated $\mathrm{OV}_{1}$ ovary. Comparison with $\mathrm{OV}_{2}$ on day 13 showed no difference in follicles from classes 2, 3 or 4 . More atretic class 5 follicles relative to the total number of follicles per ovary were found in the BFF-treated $\mathrm{OV}_{2}(P<0.05)$.

Classification of these atretic follicles suggested a more advanced atresia in follicles from BFF-treated heifers. Lower absolute (Table 2) or relative numbers and volumes of class 6 and 7 follicles were found in the BFF-treated $\mathrm{OV}_{2}$ than in control ovaries. When ovaries taken from control heifers on day 7 and day 13 were compared a greater absolute or relative number $(P<0.05 ; P<0.01)$ and volume $(P<0.01)$ of class 6 follicles on $\mathrm{OV}_{2}$ was observed compared with $\mathrm{OV}_{1}$. However, this increase in the total number and volume of follicles is mainly due to an increase in atretic follicles. Total follicular volume in class 7 of $\mathrm{OV}_{1}$ was higher than that of $O V_{2}$ in control heifers and this difference was associated with follicles in the late stages of atresia on $\mathrm{OV}_{1}$. No differences were found when $\mathrm{OV}_{1}$ and $\mathrm{OV}_{2}$ from BFF-treated heifers were compared for follicles $<3.68 \mathrm{~mm}$ in diameter. For follicles $\geq 3.68 \mathrm{~mm}$, the absolute number of follicles and follicular volumes were less $(P<0.01 ; P<0.05)$ in $\mathrm{OV}_{2}$ than in $\mathrm{OV}_{1}$. Positive correlations were found between the observations obtained macroscopically, histologically and by ultrasound scanning on $\mathrm{OV}_{\mathrm{I}}$ and $\mathrm{OV}_{2}$, with an average overall precision of $51.3 \%$ between the ultrasound and macroscopic observations $(r=0.591$, $n=22, P<0.002), 45.1 \%$ between the ultrasound and histological observations $(r=0.6155, n=22, P<0.001)$ and $72.3 \%$ between the macroscopic and histological observations $(r=0.9656, n=22, P<0.0001)$.

\section{Discussion}

Injection of charcoal-extracted BFF effectively reduced the circulating FSH concentrations in intact and hemiovariectomized postpubertal heifers. The concentration of FSH 
Table 2. Least square means ( \pm SEM) of the absolute number of histologically normal or atretic follicles in control or follicular-fluid-treated bovine ovaries on day 7 or day 13

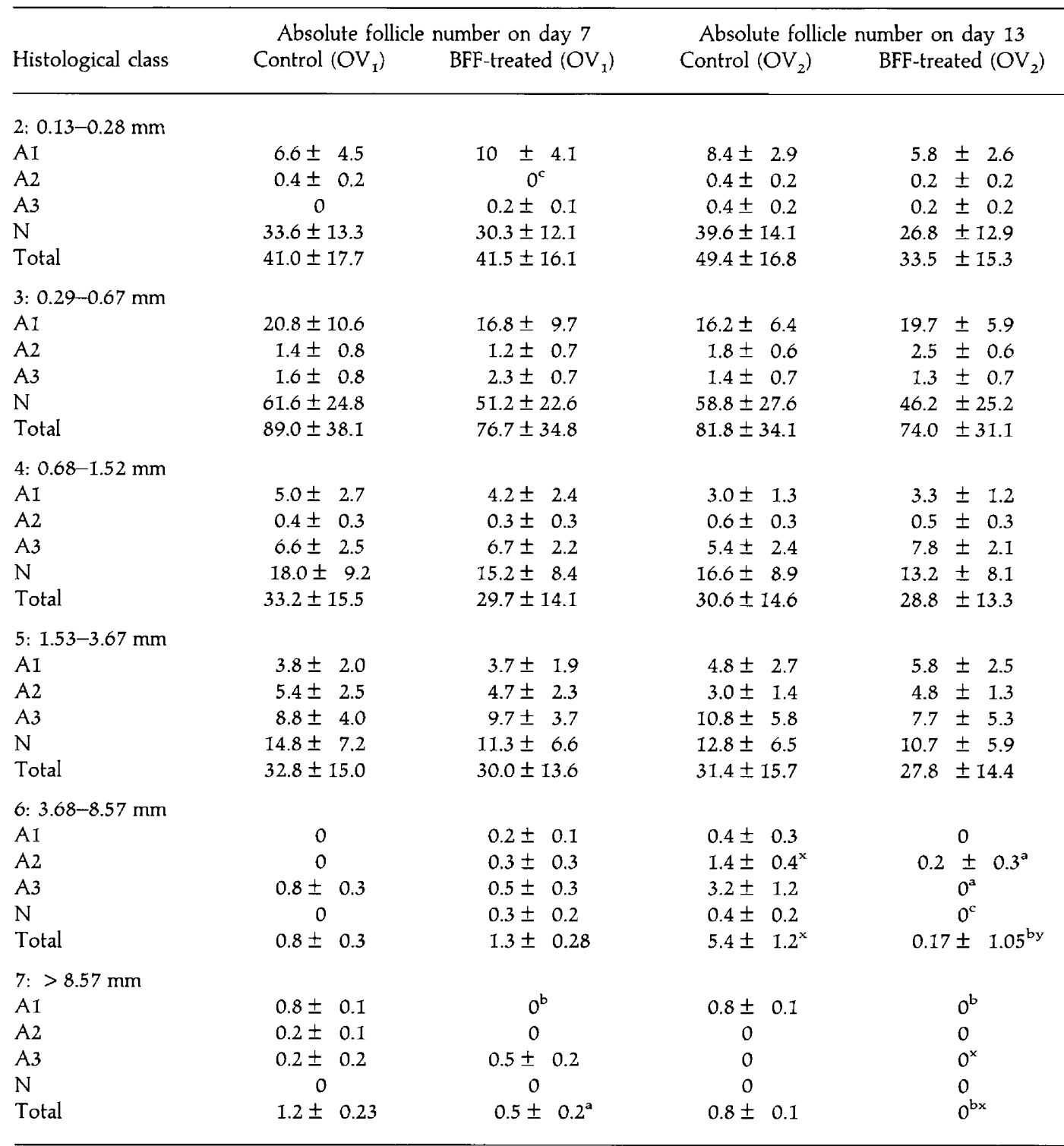

A1: atresia level 1; A2: atresia level 2; A3: atresia level 3; N: normal; Total: total number of normal and atretic follicles per histological class.

The absolute number of follicles were compared between control and BFF-treated ovaries $\left(O V_{1}\right.$ versus $O V_{1}$ and $O V_{2}$ versus $O V_{2}$ : $\left.{ }^{a} P<0.05 ;{ }^{b} P<0.01 ;{ }^{C} P<0.1\right)$ and within control or BFF-treated ovaries $\left(O V_{1}\right.$ versus $\left.\mathrm{OV}_{2}:{ }^{x} P<0.05 ;{ }^{y} P<0.01\right)$.

decreased by $31-40 \%$ within $12-24 \mathrm{~h}$ following the first injection of $\mathrm{BFF}$, and remained low during the 12 days of treatment. The suppression of circulating FSH in this experiment corresponds to the $30-45 \%$ decrease in the FSH concentration obtained in previous experiments in intact heifers (Lussier and Carruthers, 1989; Wood et al., 1993), in ovariectomized heifers injected with the $32 \mathrm{kDa}$ bovine inhibin molecule (Beard et al., 1990), and to the $30-40 \%$ maximal suppression of FSH release by BFF in dispersed bovine pituitary cells (Lussier et al., 1993). Since the radioimmunoassay reflects immunoreactive concentrations of $\mathrm{FSH}$, it cannot be determined if the residual circulating FSH concentration after BFF treatment has an altered bioactivity (Dahl et al., 1988; Wilson et al., 1990; Robertson et al., 1991).

The mean basal concentrations of LH from day 1 to day 7 were higher in BFF-treated than in control heifers; this is in contrast to previous experiments in which no such increase was detected (Lussier and Carruthers, 1989; Moser et al., 1989; Turzillo and Fortune, 1993). The major difference in this experiment is that a synthetic progesterone analogue, Norgestomet, was used to prevent ovulation after induction of luteolysis, whereas the corpora lutea had been left intact in previous experiments. The Norgestomet implant may have had a less stringent negative feedback on LH secretion, as 
suggested by previous studies (Kojima et al., 1992; Stock and Fortune, 1993), thereby allowing small changes in the steroid metabolism of the follicles to influence the activity of the hypothalamo-pituitary axis. The decrease in follicular development induced by the BFF injections, together with a lower concentration of oestradiol found in this group of heifers, supports a decreased negative feedback on LH secretion, and suggests that BFF overrides the effects of an increased concentration of $\mathrm{LH}$ on follicular development.

Injection of BFF into heifers for a period of 6 days altered follicular development. Ultrasonographical results showed that a decrease in the volume of follicles $>10 \mathrm{~mm}$ on the ovary bearing the largest follicle occurred after 6 days of BFF injections. Follicular development in control heifers was characterized by the growth of follicles $>10 \mathrm{~mm}$ in diameter and an increase in the oestradiol concentration. The lack of an increase in the concentration of oestradiol in BFF-treated heifers reflects altered follicular development. The scheme for synchronization of oestrus in the present experiment and the use of the Norgestomet implant may have altered normal follicular development by causing follicular persistency (Stock and Fortune, 1993). Despite the fact that follicular status was not monitored before the experiment, BFF prevented the development of follicles in all treated cows.

The histological studies are in agreement with the macroscopical and ultrasonographical observations: only the frequency of class 7 follicles $(>8.57 \mathrm{~mm}$ ) was lower in BFF-treated heifers. No effects were detected on numbers of follicles or their status if they were $\leq 8.57 \mathrm{~mm}$. Our follicular data suggest that BFF reduced or limited the growth of follicles in large size classes. Although no morphological effects were seen on the number or the atresia status of follicles $\leq 8.57 \mathrm{~mm}$, we cannot conclude that follicles $\leq 8.57 \mathrm{~mm}$ were not metabolically altered by the presence of exogenous BFF. In heifers that were superovulated immediately after 6 days of BFF treatment, a decrease in the mean number of corpora lutea, a smaller size of corpora lutea, and a $24 \mathrm{~h}$ delay in the preovulatory gonadotrophin surge were observed (Lussier and Carruthers, 1989). These results indicated that at the time superovulation was initiated the target follicular pool was decreased in BFF-treated heifers, and that follicles began their growth from a probable follicular pool of $<3-4 \mathrm{~mm}$.

After hemiovariectomy, the concentration of FSH in control heifers increased, reached a maximum at $36 \mathrm{~h}$ and then decreased, whereas in BFF-treated heifers FSH remained suppressed. Thus, the concentration of polypeptides (i.e. inhibin and follistatin) in the injected BFF was sufficient to overcome the effects of decreased ovarian endogenous negative feedback following hemicastration. Circulating concentrations of basal LH in both groups had a tendency to increase after hemicastration, which supports the premise that a reduced negative feedback due to reduced steroid concentrations is brought about by the removal of $\mathrm{OV}_{\mathrm{I}}$ and the less stringent negative feedback of Norgestomet. However, owing to the pulsatile nature of LH release and our infrequent blood sampling, no clear conclusion was reached.

In control heifers, follicular development as monitored by ultrasonography showed a compensatory response over time from day 7 to day 13 in follicles $\geq 4 \mathrm{~mm}$ in diameter. The increase in the number of follicles $4-6 \mathrm{~mm}$ in diameter was first observed on day 10 ( $72 \mathrm{~h}$ after hemiovariectomy), and was subsequently observed in larger size classes. Moreover, a small initial increase in the concentration of oestradiol was detected on day 12 (i.e. 5 days after hemiovariectomy), concomitant with the appearance of follicles $>10 \mathrm{~mm}$ in diameter. The circulating oestradiol concentrations observed were similar to those observed by Staigmiller and England (1982), who measured the concentrations of oestradiol in follicular fluid of growing follicles 4 days after cauterizing all follicles $>5-6 \mathrm{~mm}$. They concluded that 4 days after cautery, neither the size of the largest follicle nor production of oestradiol in the follicular fluid were indicative of a preovulatory follicle.

The compensatory process as detected by ultrasonography, and the FSH and oestradiol endocrine profiles suggest that after the ovary bearing the largest follicle is removed, ovarian inhibitors (polypeptides or steroids) are cleared from the circulation, allowing the circulating concentration of FSH to increase. This rise in FSH stimulates the development of small follicles $<4 \mathrm{~mm}$ in diameter within $36 \mathrm{~h}$ after hemiovariectomy, which is subsequently revealed in time in size 2, 3 and 4 follicles. The concentration of FSH began to decrease between 48 and $60 \mathrm{~h}$ after hemiovariectomy, before or at the time we observed an increase in the $7-10 \mathrm{~mm}$ follicles. Thereafter, the concentration of FSH decreased as more large follicles appeared ( $\geq 7 \mathrm{~mm}$ in diameter). An increase in the concentration of oestradiol on day 12 reflects the initial presence of large active and mature follicles $(>10 \mathrm{~mm})$ in control heifers. In control heifers, the negative correlations between the FSH concentration and the circulating oestradiol concentration or the mean diameter of the largest follicle support the concept that factors produced by a large dominant follicle control the circulating concentration of FSH (Lussier and Carruthers, 1989; Martin et al., 1991; Kaneko et al., 1991, 1992, 1993; Adams et al., 1992; Guilbault et al., 1992; Turzillo and Fortune, 1993).

Macroscopic and histological observations on day 13 correspond to the ultrasound observations and showed a compensatory response in the control heifers, with the presence of large follicles ( $\geq 7 \mathrm{~mm}$ ) 6 days after hemiovariectomy. These results are in agreement with the results obtained in cyclic cattle (Saiduddin et al., 1970) and prepubertal heifers (Johnson et al., 1985; Moser et al., 1989). However, the macroscopic observations on day 13 do not indicate from which follicular pool follicles were recruited to compensate for the loss of one ovary. Since antral follicle populations $\leq 8.57 \mathrm{~mm}$ are similar between ovaries (cow: Monniaux et al., 1983; Lussier et al., 1987; monkey: Koering, 1987), comparing histological data for $\mathrm{OV}_{1}$ and $\mathrm{OV}_{2}$ within control heifers indicated similar numbers of follicles $>8.57 \mathrm{~mm}$ or $<3.68 \mathrm{~mm}$; however, follicles $3.68-$ $8.57 \mathrm{~mm}$ in diameter were more numerous on $\mathrm{OV}_{2}$. Thus, the ovarian compensatory processes occurred by an increase in the number and volume of medium-sized follicles $(3.68-8.57 \mathrm{~mm})$. The large number of follicles $<3.68 \mathrm{~mm}$ and the estimated growth rate of 4 days to grow from 0.67 to $3.67 \mathrm{~mm}$ (Lussier et al., 1987) may have masked differences in the numbers of follicles in these classes, which would explain the growth of follicles $<3.68 \mathrm{~mm}$ in diameter into the larger size class ( $\geq 3.68 \mathrm{~mm}$ ). The negative correlation found in control heifers between follicles $>10 \mathrm{~mm}$ and the $7-10 \mathrm{~mm}$ follicles suggests 
that the presence of large follicles inhibits the growth of 4-6 mm follicles into the 7-10 mm follicular pool.

The increase in the overall follicular diameter from 3.68 to $8.57 \mathrm{~mm}$ in $\mathrm{OV}_{2}$ in control heifers is mainly due to an increase in atretic follicles, indicating that follicular selection is present even during the compensatory response; this is consistent with the normal ovulation rates seen after hemiovariectomy (Saiduddin et al., 1970; Merz et al., 1977; Grass and Hauser, 1981). An increase in the number of atretic follicles in control $\mathrm{OV}_{2}$ on day 13 may be attributed to the decrease in circulating FSH concentrations caused by increased follicular development and negative feedback. However, as the basal LH concentration was higher at this time compared with the initial concentration at the beginning of the experiment, increased basal $\mathrm{LH}$ concentrations associated with low FSH concentrations may also have contributed to atresia (McNeilly, 1991). Increased atresia in follicles between $3.68 \mathrm{~mm}$ and $8.57 \mathrm{~mm}$ is in agreement with the hypothesis of a selective follicular process that reduces the number of growing follicles in the final stage of follicular development and leads to follicular dominance in cattle (Adams et al., 1992; Turzillo and Fortune, 1993).

Injection of BFF inhibited the recruitment and development of follicles following hemiovariectomy. Histological data showed an absence of or a reduced number of follicles $\geq 3.68 \mathrm{~mm}$ in the BFF-treated $\mathrm{OV}_{2}$ compared with controls, but no effects were observed on the number of follicles $<3.68 \mathrm{~mm}$. It has been shown that bovine follicles $<3.68 \mathrm{~mm}$ express the FSH receptor (Wandji et al, 1992). It is thus conceivable that while small antral bovine follicles could be less susceptible to a low concentration of FSH and can maintain their metabolic activities without becoming atretic in this hormonal milieu, such a hormonal condition is detrimental to the survival of follicles $\geq 3.68 \mathrm{~mm}$ in diameter.

The largest follicles on $O V_{1}$ between day 1 and day 7 and on $\mathrm{OV}_{2}$ between day 7 and day 13 in control heifers had a similar mean growth rate $\left(1.6 \mathrm{~mm}\right.$ day $\left.^{-1}\right)$. These estimated growth rates for medium-large sized follicles (i.e. $\geq 4 \mathrm{~mm}$ ) are in agreement with histological (Lussier et al., 1987) and ultrasonographical observations (Quirk and Fortune, 1986; Sirois and Fortune, 1988; Knopf et al., 1989; Kastelic et al., 1990) obtained at different times of the oestrous cycle. If follicles are recruited at $<4 \mathrm{~mm}$ and if their growth rate is around $1.6 \mathrm{~mm}$ per day, at least 2 days would be required for a follicle to reach $7.2 \mathrm{~mm}$. This estimation corresponds to our ultrasonography data, as more follicles of diameter 4-6 mm were observed approximately 2 days after circulating FSH concentrations reached a maximum, and it also agrees with the observations of Adams et al. (1992) from intact BFF-treated cows. There is a similarity between the increased postovulatory FSH rise during the oestrous cycle and the posthemiovariectomized FSH rise. The postovulatory increase in the FSH concentration is necessary to recruit the dominant follicle that reaches its maximum size on day 7-8 of the oestrous cycle (Turzillo and Fortune, 1990). As the postovulatory FSH rise is detected approximately $48 \mathrm{~h}$ after the preovulatory gonadotrophin surge, if follicles $>3-4 \mathrm{~mm}$ are atretic during this period, and recruited follicles $<4 \mathrm{~mm}$ are growing at a rate of $1.6 \mathrm{~mm} \mathrm{day}^{-1}$, the diameter of the first dominant follicle should be about 9-12 mm on days $6-8$. This is a similar value to the maximum diameter reached and observed by ultrasonography (Sirois and
Fortune, 1988; Turzillo and Fortune, 1990, 1993; Adams et al., 1992).

We observed that follicular recruitment and development beyond a diameter of $3.68 \mathrm{~mm}$ in cattle depends on an adequate circulating concentration of FSH. The results reported here indicate that polypeptides present in BFF inhibit follicular development by acting on the pituitary to reduce the release of FSH (Lussier and Carruthers, 1989; Moser et al., 1989; Adams et al., 1992; Lussier et al., 1993; Turzillo and Fortune, 1993; Wood et al., 1993). Kaneko et al. (1993) observed an increase in the number of follicles $4-7 \mathrm{~mm}$ in diameter $48 \mathrm{~h}$ after passive immunization against inhibin. Their results support the concept of a physiological blockade of follicular development beyond growth to $3.68 \mathrm{~mm}$ through the action of inhibin at the pituitary to reduce FSH synthesis and release. Results obtained in cattle (Law et al., 1992) and in sheep (Larson et al., 1991) suggest that polypeptide factors present in BFF may also alter follicular development by acting directly on the ovary. However, a direct effect of BFF on cow ovaries was not supported by the results of Moser et al. (1989). Thus, the design of the present experiment cannot rule out a possible direct effect of BFF on the ovary or that polypeptide factors present in BFF contributed to an alteration in follicular growth. Both mechanisms of action are possible, indirect (mediated through the pituitary) or direct (mediated through the ovary), but the relative importance of each mechanism remains to be determined.

Granulosa cell mitotic activity increases significantly in follicles $0.68-3.67 \mathrm{~mm}$ in diameter, at which time a marked increase in antrum size relative to the granulosa layer occurs (Lussier et al., 1987). The ovarian histological data of the present experiment showed that atresia of $9.5 \%$ in class 3 $(0.29-0.67 \mathrm{~mm})$ follicles increased to $36.1 \%$ (excluding atresia status 1$)$ in class $4(0.68-1.52 \mathrm{~mm})$ follicles. These data are in agreement with our previous results (Lussier et al., 1987). In follicles $\geq 3.68 \mathrm{~mm}$ in diameter, an increase in atretic follicles of up to $86.9 \%$ was observed. It is also at this stage that inhibition of follicular growth by BFF occurs. With these results and the model proposed by Hirshfield (1991) in rats, we postulate that follicles of $0.68-3.67 \mathrm{~mm}$ in diameter displaying increased granulosa cell mitotic activity associated with a markedly increased antrum size are prevented from entering their final stage of differentiation by a lack of FSH. This final differentiated state of granulosa cells may induce increased follicular metabolic requirements to support and sustain the final and rapid follicular growth; otherwise, the follicle becomes atretic. FSH would stimulate entry into and sustain the growth of follicles beyond the $3-4 \mathrm{~mm}$ stage. A decrease in the circulating concentration of FSH by a growing dominant follicle would therefore precipitate atresia in follicles that are $>3-4 \mathrm{~mm}$ owing to the lack of adequate FSH support (Zeleznick and Kubic, 1986; Adams et al., 1992; Turzillo and Fortune, 1993).

The authors thank L. E. Reichert, Jr, Albany Medical College, Albany, NY for purified bovine LH, G. D. Niswender, Colorado State University, Fort Collins, CO for the LH antiserum, J. G. Manns and N. Rawlings, University of Saskatchewan, Saskatoon for the sheep anti-rabbit antibody and steroid antisera, the National Hormone and Pituitary Program (Bethesda, MD) for providing materials for the radioimmunoassays of $\mathrm{FSH}$ and $\mathrm{LH}$, and A-M. Taillefer for technical 
assistance. This research was supported by a grant from the Natural Sciences and Engineering Research Council of Canada, the Research Branch of Agriculture Canada and CORPAQ.

\section{References}

Adams GP, Matteri RL, Kastelic JP, Ko JCH and Ginther OJ (1992) Association between surges of follicle-stimulating hormone and the emergence of follicular waves in heifers Journal of Reproduction and Fertility 94 177-188

Allen OB, Burton JH and Holt JD (1983) Analysis of repeated measurements from animal experiments using polynomial regression Journal of Animal Science 57 765-770

Beard AJ, Savva D, Glencross RG, McLeod BJ and Knight PG (1989) Treatment of ovariectomized heifers with bovine follicular fluid specifically suppresses pituitary levels of FSH- $\beta$ mRNA Journal of Molecular Endocrinology 3 85-91

Beard AJ, Castillo RJ, McLeod BJ, Glencross RG and Knight PG (1990) Comparison of the effects of crude and highly purified bovine inhibin (Mr 32000) on plasma concentrations of $\mathrm{FSH}$ and $\mathrm{LH}$ in chronically ovariectomized prepubertal heifers Joumal of Endocrinology 125 21-30

Cook SJ, Rawlings NC and Kennedy RI (1982) Quantitation of six androgens by combined high performance liquid chromatography and radioimmunoassay Steroids 40 369-380

Dahl K, Bisack TA and Hsueh AJW (1988) Naturally occurring antihormones: secretion of FSH antagonists by women treated with a $\mathrm{GnRH}$ analog Science $23972-74$

Dalkin AC, Knight CD, Shupnik MA, Haisenleder DJ, Aloi J, Kirk SE, Yasin M and Marshall JC (1993) Ovariectomy and inhibin immunoneutralization acutely increase follicle-stimulating hormone- $\beta$ messenger ribonucleic acid concentrations: evidence for a nontranscriptional mechanism Endocrinology 132 1297-1304

England BG, Hauser ER and Casida LE (1973) Some effects of unilateral ovariectomy in the postpartum beef cow Journal of Animal Science 36 45-50

Fortune JE (1994) Ovarian follicular growth and development in mammals Biology of Reproduction $\mathbf{5 0} 225-232$

Grass J and Hauser ER (1981) The influence of early age mastectomy and unilateral ovariectomy on reproductive performance of the bovine Journal of Animal Science 53 171-176

Grimes RW, Matton P and Ireland JJ (1987) A comparison of histological and non-histological indices of atresia and follicular function Biology of Reproduction $3782-88$

Guilbault LA, Grasso F, Lussier JG, Rouillier P and Matton P (1991) Decreased superovulatory responses in heifers superovulated in the presence of a dominant follicle Joumal of Reproduction and Fertility 91 81-89

Guilbault LA, Lussier JG and Grasso F (1992) Interrelationships of hormonal and ovarian responses in superovulated heifers pretreated with FSH-P at the beginning of the estrous cycle Theriogenology 37 1029-1040

Hafez ESE, Rajakoski E, Anderson PB, Frost OL and Smith G (1964) Problems of gonadotropin-induced multiple pregnancy in beef cattle American journal of Veterinary Research 25 1074-1079

Hirshfield AN (1991) Development of follicles in the mammalian ovary International Review of Cytology 124 43-101

Ireland JJ, Curato AD and Wilson J (1983) Effect of charcoal-treated bovine follicular fluid on secretion of $\mathrm{LH}$ and FSH in ovariectomized heifers Journal of Animal Science 57 1512-1516

Johnson SK, Smith MF and Elmore RG (1985) Effect of unilateral ovariectomy and injection of bovine follicular fluid on gonadotropin secretion and compensatory ovarian hypertrophy in prepubertal heifers Journal of Animal Science $601055-1060$

Kaneko H, Terada T, Watanebe G, Taya K, Sasamoto S, Hasegawa $Y$ and Igarashi $M$ (1991) Ovarian follicular dynamics and concentrations of estradiol-17 $\beta$, progesterone, luteinizing hormone and follicle stimulating hormone during the periovulatory phase of the estrous cycle in the cow Reproduction, Fertility and Development 3 529-535

Kaneko H, Watanabe G, Taya K and Sasamoto S (1992) Changes in peripheral levels of bioactive and immunoreactive inhibin, estradiol-17 $\beta$, progesterone, luteinizing hormone, and follicle-stimulating hormone associated with follicular development in cows induced to superovulate with equine chorionic gonadotropin Biology of Reproduction 47 76-82
Kaneko H, Nakanishi Y, Taya K, Kishi H, Watanabe G, Sasamoto S and Hasegawa $Y$ (1993) Evidence that inhibin is an important factor in the regulation of FSH secretion during the mid-luteal phase in cows Joumal of Endocrinology $136 \quad 35-41$

Kastelic JP, Ko JCH and Ginther OJ (1990) Suppression of dominant and subordinate ovarian follicles by a proteinaceous fraction of follicular fluid in heifers Theriogenology 34 499-509

Knight PG (1991) Identification and purification of inhibin and inhibin-related proteins Journal of Reproduction and Fertility Supplement 43 111-113

Knopf L, Kastelic JP, Schallenberger E and Ginther OJ (1989) Ovarian follicular dynamics in heifers: test of two-wave hypothesis by ultrasonically monitoring individual follicles Domestic Animal Endocrinology 6 111-119

Koering MJ (1987) Follicle maturation and atresia: morphological correlates. In The Primate Ovary pp 3-23 Ed. RL Stouffer. Plenum Press, New York

Kojima N, Stumpf TT, Cupp AS, Werth LA, Roberson MS, Wolfe MW, Kittok RJ and Kinder JE (1992) Exogenous progesterone and progestins as used in estrous synchrony regimens do not mimic the corpus luteum in regulation of luteinizing hormone and $17 \beta$-estradiol in circulation of cows Biology of Reproduction 47 1009-1017

Kruip ThAM and Dieleman SJ (1982) Macroscopic classification of bovine follicles and its validation by micromorphological and steroid biochemical procedures Reproduction Nutrition Development 22 465-473

Larson GH, Mallory DS, Dailey RA and Lewis, PE (1991) Gonadotropin concentrations, follicular development, and luteal function in pituitary stalktransected ewes treated with bovine follicular fluid Journal of Animal Science 69 4104-4111

Law AS, Baxter G, Logue DN, O'Shea T and Webb R (1992) Evidence for the action of bovine follicular fluid factor(s) other than inhibin in suppressing follicular development and delaying oestrus in heifers Journal of Reproduction and Fertility $96603-616$

Lussier JG and Carruthers TD (1989) Endocrine and superovulatory responses in heifers pretreated with FSH or bovine follicular fluid Theriogenology 31 779-794

Lussier JG, Matton P and Dufour JJ (1987) Growth rates of follicles in the ovary of the cow Journal of Reproduction and Fertility 81 301-307

Lussier JG, Carruthers TD and Murphy BD (1993) Effects of bovine follicular fluid and partially purified bovine inhibin on FSH and LH release by bovine pituitary cells in culture Reproduction Nufrition Development 33 109-119

McNeilly AS (1991) The ovarian follicle and fertility Journal of Steroid Bio chemistry and Molecular Biology 40 29-33

Martin TL, Fogwell RL and Ireland JJ (1991) Concentrations of inhibins and steroids in follicular fluid during development of dominant follicles in heifers Biology of Reproduction 44 693-700

Merz EA, Henning GF, Hauser ER and Casida LE (1977) An attempt to induce multiple ovulations in beef cows by unilateral ovariectomy and hCG administration Journal of Animal Science 46 492-495

Miller KF, Critser JK, Rowe RF and Ginther OJ (1979) Ovarian effects of bovine follicular fluid treatment in sheep and cattle Biology of Reproduction 21 537-544

Monniaux D, Chupin D and Saumande J (1983) Superovulatory responses of cattle Theriogenology 19 55-81

Moser MT, Garverick HA, Smith MF and Younguist RS (1989) Effect of bovine follicular fluid and follicle-stimulating hormone on follicular growth in unilaterally ovariectomized prepubertal heifers Journal of Dairy Science $\mathbf{7 2}$ 2170-2178

Quirk SM and Fortune JE (1986) Plasma concentrations of gonadotrophins, preovulatory follicular development and luteal function associated with bovine follicular fluid-induced delay of oestrus in heifers Journal of Reproduction and Fertility 76 609-621

Rawlings NC, Jeffcoate IA and Rieger DL (1984) The influence of estradiol-17 $\beta$ and progesterone on peripheral serum concentrations of luteinizing hormone and follicle stimulating hormone in the ovariectomized ewe Theriogenology 22 473-488

Robertson DM, Foulds LM, Fry RC, Cummins JT and Clarke I (1991) Circulating half-lives of follicle-stimulating hormone and luteinizing hormone in pituitary extracts and isoform fractions of ovariectomized and intact ewes Endocrinology 129 1805-1813

Rowell JE and Flood PF (1988) Progesterone, oestradiol-17 $\beta$ and LH during the oestrous cycle of muskoxen (Ovibos moschatus) Journal of Reproduction and Fertility 84 117-122

Saiduddin S, Rowe RF and Casida LE (1970) Ovarian follicular changes following unilateral ovariectomy in the cow Biology of Reproduction 2 408-412

SAS (1985) SAS User's guide: Statistics (5th Edn). SAS Institute Inc., Cary, NC 
Short CE (1987) Principles and Practice of Veterinary Anesthesia. Williams and Wilkins, Baltimore

Sirois J and Fortune JE (1988) Ovarian follicular dynamics during the estrous cycle in heifers monitored by real-time ultrasonography Biology of Reproduction 39 308-317

Staigmiller RB and England BG (1982) Folliculogenesis in the bovine Theriogenology $1743-52$

Stock AE and Fortune IE (1993) Ovarian follicular dominance in cattle: relationship between prolonged growth of the ovulatory follicle and endocrine parameters Endocrinology 132 1108-1114

Turzillo AM and Fortune JE (1990) Suppression of the secondary FSH surge with bovine follicular fluid is associated with delayed ovarian follicular development in heifers Journal of Reproduction and Fertility 89 643-653

Turzillo AM and Fortune JE (1993) Effects of suppressing plasma FSH on ovarian follicular dominance in cattle Journal of Reproduction and Fertility 98 113-119

Wandji SA, Pelletier G and Sirard MA (1992) Ontogeny and cellular localization of ${ }^{125} \mathrm{I}$-labeled insulin-like growth factor-I, ${ }^{125} \mathrm{I}$-labeled follicle-stimulating hormone, and ${ }^{125} \mathrm{I}$-labeled human chorionic gonadotropin binding sites in ovaries from bovine fetuses and neonatal calves Biology of Reproduction 4 814-822

Webb R, Gong JG, Law AS and Rusbridge SM (1992) Control of ovarian function in cattle Joumal of Reproduction and Fertility Supplement $\mathbf{4 5}$ 141-156

Wilson CA, Leigh AJ and Chapman AJ (1990) Gonadotrophin glycosylation and function Joumal of Endocrinology 125 3-14

Wood SC, Glencross RG, Bleach EC, Loveil R, Beard AJ and Knight PG (1993) The ability of steroid-free bovine follicular fluid to suppress FSH secretion and delay ovulation persists in heifers actively immunized against inhibin Journal of Endocrinology 136 137-148

Zeleznik AJ and Kubik CJ (1986) Ovarian responses in macaques to pulsatile infusion of follicle-stimulating hormone (FSH) and luteinizing hormone: increased sensitivity of the maturing follicle to FSH Endocrinology 119 2025-2032

Zollers WG, Forrest DW, Campbell WJ, Parfet JR, Smith MF, Harms PG and Garverick HA (1989) Ovarian inhibition of peripheral plasma concentration of follicle stimulating hormone in prepubertal Holstein heifers Domestic Animal Endocrinology 6 35-40 